\title{
A Study to Assess the knowledge of Nursing Staff Regarding Needle Stick Injury in Selected Hospital Mysore
}

\author{
Lakshmi KN* \\ Principal, Vikram College of Nursing, Mysore, India
}

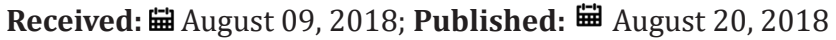

*Corresponding author: Lakshmi KN, Principal, Vikram College of Nursing, Mysore, India

\section{Abstract}

Background of the study: Needle stick injuries (NSIs) are among the most common accidents reported by healthcare workers, including doctors, nurses and non-clinical staff.

\section{Objectives:}

a) To assess the level of knowledge of nursing staff regarding needle stick injury.

b) To find the association between knowledge scores of nursing staff regarding needle stick injury with their selected personal variables.

Methodology: Formal administrative permission was obtained from Institution prior to data collection. Informed consent was obtained from the samples. 60 samples were selected by using non-probability convenience sampling technique. Data was collected by administering personal proforma and structured knowledge questionnaire regarding needle stick injury. Staff took $30 \mathrm{~min}$ to fill the questions. Data collection process was terminated by thanking the samples.

Results: $1(1.6 \%)$ nursing staff had poor knowledge,24(40\%) had average knowledge and 35(58.3\%) had good knowledge regarding needle stick injury. There was no association found between knowledge of nursing staff regarding needle stick injury and their selected persona variables.

Keywords: Nursing staff; Needle Stick Injury

\section{Introduction}

Needle stick injuries (NSIs) are among the most common accidents reported by healthcare workers, including doctors, nurses and non-clinical staff. This is particularly worrying because hospital workers who are pricked with a needle may be at risk of contracting viruses that are carried in the bloodstream. The most serious of these include HIV and Hepatitis C. Over the past two decades, efforts have been made to reduce the rate of NSIs. The average risk of transmission of HIV to a health care worker after percutaneous exposure to HIV-infected blood has been estimated as 3 in 1000 [1]. Needle stick injuries have significant indirect consequences in health care delivery especially so in the developing countries, where already the qualified work force is limited with respect to the disease burden in the population. These injuries not only potentiate health consequences but also cause emotional distress in health care workers which results in missed workdays and directly affects the health care services and resources [2].

\section{Need for the Study}

According to a WHO study, the annual estimated proportions of health-care workers (HCW) exposed to blood-borne pathogens globally were $2.6 \%$ for $\mathrm{HCV}, 5.9 \%$ for $\mathrm{HBV}$, and $0.5 \%$ for $\mathrm{HIV}$, corresponding to about $16,000 \mathrm{HCV}$ infections and 66,000 HBV infections in HCW worldwide [3].

\section{Statement of the Problem}

A study to assess the level of knowledge of nursing staff regarding needle stick injury in selected hospitals at Mysore.

\section{Objectives of the Study}

a) To assess the level of knowledge of nursing staff regarding needle stick injury

b) To find the association between knowledge scores of nursing staff regarding needle stick injury with their selected personal variables.

\section{Hypothesis}

H1: there will be a significant association between knowledge of nursing staff regarding needle stick injury with their selected personal variables. 


\section{Assumptions}

Nursing staff may have some knowledge regarding needle stick injury.

\section{Methodology}

Research approach and design: Descriptive research design

Variables of the study: knowledge of nursing staff regarding needle stick injury

Setting: Selected Hospital, Mysore

Population: Nursing staff

Sample and sample size: 60 nursing staff

Sampling technique: No probability Convenience Sampling technique

\section{Criteria for Sampling \\ Inclusion Criteria}

Nursing staff who are:
a) Available at the data of data collection.
b) Willing to participate.

\section{Instrument used for Data Collection}

Section 1: Personal proforma to assess the personal variables such as age, sex, educational qualification, years of experience and department they work.

Section 2: structured knowledge questionnaire to assess the level of knowledge regarding needle stick injury total 25 items which was developed with the help of research articles on meaning, causes, classification, prevention and management.

Scoring: Poor knowledge -0-10

Average knowledge 11-20

Good knowledge 21-30.

\section{Data Collection Procedure}

Formal administrative permission was obtained from Institution prior to data collection. Informed consent was obtained from the samples. 60 samples were selected by using non probability convenience sampling technique. Data was collected by administering personal proforma and structured knowledge questionnaire regarding needle stick injury. Staff took $30 \mathrm{~min}$ to fill the questions. Data collection process was terminated by thanking the samples.

Table 1: Frequency and percentage distribution to assess the sample characteristics. $n=60$.

\begin{tabular}{|c|c|c|c|}
\hline Sl no & Personal variables & Frequency & Percentage(\%) \\
\hline 1 & $\begin{array}{c}\text { Age } \\
\text { a)22-30 years } \\
\text { b) 31-40 years } \\
\text { c)above } 40 \text { years }\end{array}$ & $\begin{array}{l}56 \\
4 \\
0\end{array}$ & $\begin{array}{c}93.3 \\
6.7 \\
0\end{array}$ \\
\hline 2 & \begin{tabular}{lr} 
& \multicolumn{2}{c}{ Sex } \\
a) & Male \\
b) & Female
\end{tabular} & $\begin{array}{c}2 \\
58\end{array}$ & $\begin{array}{c}3.3 \\
96.7\end{array}$ \\
\hline 3 & $\begin{array}{l}\text { Educational qualification } \\
\qquad \begin{array}{c}\text { a)GNM } \\
\text { b) } B S c(N) \\
\text { c) } \operatorname{PBBSc}(\mathrm{N})\end{array}\end{array}$ & $\begin{array}{c}57 \\
2 \\
1\end{array}$ & $\begin{array}{l}95 \\
3.3 \\
1.7\end{array}$ \\
\hline 4 & 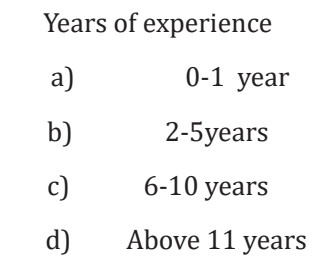 & $\begin{array}{c}32 \\
23 \\
3 \\
2\end{array}$ & $\begin{array}{c}53.3 \\
38.3 \\
5 \\
3.3\end{array}$ \\
\hline 5 & $\begin{array}{l}\text { Department they work } \\
\text { a)Emergency ward } \\
\text { b) ICU }\end{array}$ & $\begin{array}{c}4 \\
56\end{array}$ & $\begin{array}{c}6.7 \\
93.3\end{array}$ \\
\hline
\end{tabular}

Table 2: Frequency and percentage distribution of knowledge scores of nursing staff regarding needle stick injury. $\mathrm{n}=60$.

\begin{tabular}{|c|c|c|}
\hline Level of knowledge & Frequency & \multicolumn{2}{c|}{ Percentage (\%) } \\
\hline Poor & 1 & 1.66 \\
\hline Average & 24 & 40 \\
\hline Good & 35 & 58.3 \\
\hline
\end{tabular}




\section{Results: (Tables 1-3)}

Table 3: Mean. Median and standard deviation scores knowledge scores of nursing staff regarding needle stick injury. $n=60$.

\begin{tabular}{|c|c|c|c|}
\hline Group & Mean & Median & $\begin{array}{c}\text { Standard } \\
\text { deviation }\end{array}$ \\
\hline $\begin{array}{c}\text { Nursing } \\
\text { students }\end{array}$ & 20.10 & 23.5 & \pm 10.32 \\
\hline
\end{tabular}

\section{Conclusion}

The present study revealed that knowledge scores of nursing staff regarding needle stick injury $1(1.66 \%)$ had poor knowledge, $25(41.66 \%)$ had average knowledge and 34(56.66\%) had good knowledge among nursing staff.

\section{Recommendations}

a) Similar study can be conducted by using true experimental approach

ISSN: 2574-1241

DOI: 10.26717/BJSTR.2018.08.001613

Lakshmi KN. Biomed J Sci \& Tech Res

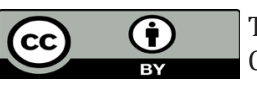

This work is licensed under Creative Commons Attribution 4.0 License

Submission Link: https://biomedres.us/submit-manuscript.php b) A study can be conducted to assess the effectiveness of STP on knowledge of nursing staff regarding needle stick injury.

c) Study can be done to compare the knowledge of nursing staff regarding needle stick injury among private and government hospitals.

\section{References}

1. https://www.myvmc.com/lifestyles/preventing-needle-stick-injuries/

2. Wittmann, A Hofmann, F Kralj (2007) 'Needle Stick Injuries - Risk from Blood Contact in Dialysis'. Journal of Renal Care 33(2): 70-73.

3. Whitby M, McLaws ML (2002) 'Hollow-bore needle stick injuries in a tertiary teaching hospital: epidemiology, education and engineering'. MJA 177(8): 418-422.

4. www.omnicsoline.org

5. www.ajicjournal.org.

6. https://academic.oup.com/journals.

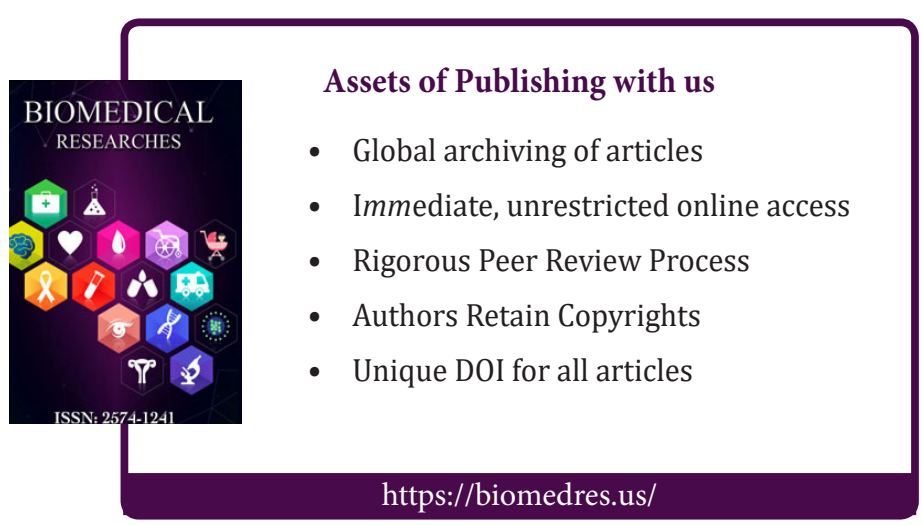

